\title{
ArcheoSciences
}

Revue d'archéométrie

\section{The first gold coins struck in Brazil: myth or reality?}

Les premières monnaies en or frappées au Brésil : mythe ou réalité?

Mathieu Duttine, Maria Filomena Guerra, Rejane Maria Lobo Vieira, Rosa B. Scorzelli, Carlos Eduardo Pereira and Carlos A. Perez

\section{(2) OpenEdition}

Electronic version

URL: http://journals.openedition.org/archeosciences/2383

DOI: 10.4000/archeosciences.2383

ISBN: 978-2-7535-1598-7

ISSN: 2104-3728

Publisher

Presses universitaires de Rennes

Printed version

Date of publication: 31 December 2009

Number of pages: $309-312$

ISBN: 978-2-7535-1181-1

ISSN: 1960-1360

\section{Electronic reference}

Mathieu Duttine, Maria Filomena Guerra, Rejane Maria Lobo Vieira, Rosa B. Scorzelli, Carlos Eduardo

Pereira and Carlos A. Perez, "The first gold coins struck in Brazil: myth or reality? ", ArcheoSciences [Online], 33 | 2009, Online since 10 December 2012, connection on 30 April 2019. URL : http:// journals.openedition.org/archeosciences/2383; DOI : 10.4000/archeosciences.2383 


\title{
The first gold coins struck in Brazil: myth or reality?
}

\author{
Les premières monnaies en or frappées au Brésil : mythe ou réalité?
}

\author{
Mathieu Duttine*, Maria Filomena Guerra**, Rejane Maria Lobo Vieira***, \\ Rosa B. Scorzelli****, Carlos Eduardo Pereira***** \\ and Carlos A. Perez ${ }^{* * * * * *}$
}

\begin{abstract}
Besieged in Pernambuco by the Portuguese, the Dutch issued in 1645 and 1646, to pay their soldiers, the first coin inscribed "BRASIL". Named obsidional, it is said to have been fabricated by melting either African gold or gold tableware. It is only in 1694 that the Brazilian itinerant mint was created in Bahia, and successively closed and transferred to Rio de Janeiro in 1698, to Pernambuco in 1700, and back to Rio de Janeiro in 1702. This itinerary is related to the exhaustion of the local metal supplies, until the discovery of gold in Brazil in the late 1600s. SR-XRF analyses of a small set of coins issued by the Dutch West Indies Company and the first Rio de Janeiro mint show the use of different gold alloys and the ratios of trace elements allow advancing several assumptions on the provenance of the gold.

Résumé : Afin de payer la solde de leurs soldats assiégés par les Portugais à Pernambuco, les Hollandais frappèrent, en 1645 et 1646, les premières monnaies portant l'inscription "BRASIL", dites obsidionales, à partir de la fonte d'or africain ou de vaisselle d'or. Ce n'est qu'en 1694 que le premier atelier itinérant brésilien fut créé à Bahia; il fut ensuite fermé et transféré à Rio de Janeiro en 1698, puis à Pernambuco en 1700 avant de sinstaller de nouveau à Rio de Janeiro en 1702. Ces délocalisations successives apparaissent liées à l'épuisement des stocks de métal jusqu'aux découvertes de gisements d'or au Brésil à la fin du XVI siècle. L'analyse par SR-XRF de quelques monnaies émises par la Compagnie Hollandaise des Indes Occidentales et d'autres frappées par le premier atelier de Rio de Janeiro indique que l'utilisation de différents alliages d'or et les teneurs en certains éléments traces apportent quelques indices quant à la provenance de l'or.
\end{abstract}

Keywords: Gold, Brasil, obsidional, coin, SR-XRF.

Mots-clés : or, Brésil, monnaie, obsidional, SR-XRF.

\section{INTRODUCTION}

Until the end of the $17^{\text {th }}$ century, many Spanish and Portuguese coins circulated in Brazil with countermarks, which were applied during temporary operating periods in the Capitanias mints. Only emergency issues were struck in 1645 and 1646 by the Dutch to pay their soldiers, besieged on the Pernambuco coast by the Portuguese. The obsidional coins are the very first coins having Brasil inscribed on the reverse and G.W.C. (Geoctroyeerde Westindische

\footnotetext{
* Institut de Chimie de la Matière Condensée de Bordeaux. UPR 9048 CNRS-87, Avenue du Docteur-Albert-Schweitzer, 33608 Pessac cedex, France. (m.duttine@icmcb-bordeaux.cnrs.fr)

** Laboratoire du Centre de Recherche et de Recherche et de Restauration des Musées de France, UMR171 CNRS - 14, quai François-Mitterrand, 75001 Paris, France. (maria.guerra@culture.gouv.fr)

*** Museu Histórico Nacional, Acervo de Numismática - Praça Marechal Âncora, s/n 20021-200 Rio de Janeiro-RJ, Brazil.

**** Centro Brasileiro de Pesquisas Físicas - Rua Dr. Xavier Sigaud 150, Urca-Rio de Janeiro, 22290-180, Brazil. (scorza@cbpf.br)

****** Instituto Nacional de Tecnologia (INT) - Rua Venezuela 82, 20081-312, Rio de Janeiro, Brazil.

****** Laboratório Nacional de Luz Sincrotron-LNLS/CNPq - Caixa Postal 6192, 13038-970 Campinas, Brazil. (perez@lnls.br)
} 
Compagnie), indicating the West Indies Company, on the obverse. They could have been issued using African gold brought by the ships circulating between the Netherlands, the African coast (to take gold), and Brazil (to take sugar and pau-brasil) or by simple melting of gold and silver tableware (Vieira et al., 2007).

It was only on the $8^{\text {th }}$ of March 1694 that a royal decree by Peter II (1667-1706) created the Brazilian mint in Bahia, which was successively closed and transferred to Rio de Janeiro in 1698 , to Pernambuco in 1700 , and back to Rio de Janeiro in 1702 (Lima, 2005). This itinerary is supposed to be related to the exhaustion of the metal supplies, until the discovery of gold in the state of Minas Gerais in 1695 (Noya Pinto, 1979). In a previous work, it was shown that the first Bahia mint (1694-1698) struck a mixture of Colombian and other Latin American gold, certainly part of the old supplies, while the second Bahia mint (after 1714) struck a gold typical of the new Brazilian sources in Minas Gerais (Guerra, 2004).

The aim of the present study is to confirm whether the same practice was observed in the first Rio de Janeiro mint, issuing coins in 1699 and 1700, and to provide valuable information regarding the gold used to issue the obsidional gold coins.

\section{Methods and Results}

All the gold coins studied in this work belong to the collection of the Museu Histórico Nacional (MHN), Rio de Janeiro. Six coins of 1.000, 2.000 and 4.000 réis issued in 1699 and 1700 by the Rio de Janeiro mint (Fig. 1a) and four obsidional coins (III, VI and XII florins) struck by the Dutch West Indies Company in 1645 and 1646 (Fig. 1b) were selected for analysis by Synchrotron Radiation X-ray Fluorescence (SR-XRF) at the Laboratório Nacional de Luz Sincrotron (LNLS), Campinas, Brazil. Micro-SR-XRF analyses were performed in air with an incident photon energy of $4.2 \mathrm{keV}$ provided by a $\mathrm{Si}(111)$ double crystal (channel-cut type) monochromator (energy resolution $\Delta \mathrm{E} / \mathrm{E}=3.10^{-4}$ in the 4-14 keV energy range). The photon flux was about 4-x-10 photons/s. The characteristic X-rays were collected in energydispersive mode by a $\mathrm{Ge}(\mathrm{Li})$ detector $(150 \mathrm{eV} \mathrm{FWHM}$ at 4.2 $\mathrm{keV}$ ) positioned at an angle of $90^{\circ}$ with respect to the incident beam. The SR-XRF data was analysed with the AXIL software (Van Espen et al., 1977) in order to evaluate the contribution to ED-XRF spectra of several elements, such as $\mathrm{Au}, \mathrm{Ag}, \mathrm{Cu}$, $\mathrm{Pb}, \mathrm{Hg}, \mathrm{Pt}, \mathrm{Pd}, \mathrm{Sn}, \mathrm{Sb}$ and $\mathrm{Zn}$. Samples of known composition were used as calibration standards to estimate the atomic concentrations of these elements in the analysed gold coins.

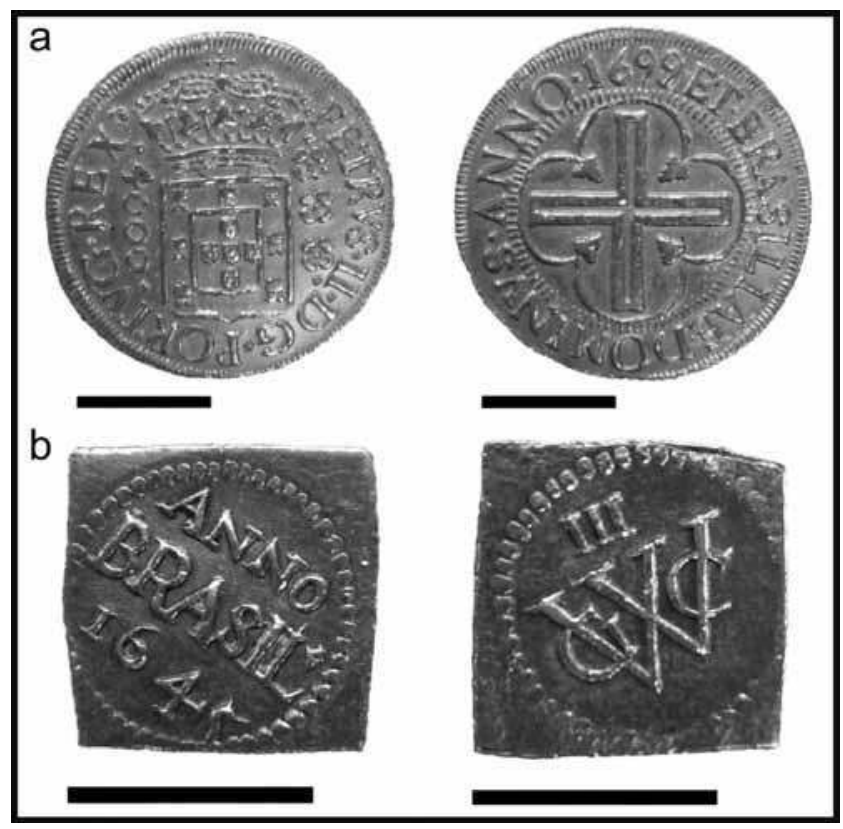

Figure 1: (See colour plate) (a) 4.000 réis gold coin from the mint of Rio de Janeiro (1699); (b) III florins obsidional gold coin struck in Brazil (1645) for the Dutch West Indies Company.

Figure 1: (Voir planche couleur) (a) Monnaie en or de 4000 réis frappée par l'atelier de Rio de Janeiro (1699); (b) monnaie obsidional en or frappée au Brésil (1645) pour la Compagnie Hollandaise des Indes Occidentales.

Unfortunately, some experimental problems (parasitic X-ray emissions of unidentified origin) rendered impossible the measurement or even estimation of the $\mathrm{Pt}$ and $\mathrm{Hg}$ contents for all the analysed coins.

Table 1 shows the results obtained for the gold coins analysed by SR-XRF. The ternary diagram in Figure 2a shows that the base alloys used for the fabrication of the obsidional coins differ from those used in the Rio de Janeiro and Bahia mints; these two mints were issuing coins, except one, of equivalent fineness and close silver and copper contents. Figure $2 \mathrm{~b}$ shows the concentrations of $\mathrm{Sn}, \mathrm{Sb}$ and $\mathrm{Pd}$ (in $\mathrm{ppm}$ ) normalised to the concentrations of gold in $\%$ and to $100 \%$, for the coins issued in Rio de Janeiro analysed in this work and the coins issued in Bahia, published in a previous work (Guerra, 2004). It is clear from this diagram that the metal used in Rio de Janeiro is close to the gold used in the first Bahia mint. However, the impossibility to quantify the Pt content for the Rio de Janeiro issues does not allow confirming the use of Latin American gold.

The obsidional coins were fabricated with a different gold. However, the concentrations of Sn, Sb and Pd are clearly distinct from the results obtained for both the Islamic coins struck in Northern Africa with local gold (Godonneau and 


\begin{tabular}{|c|c|c|c|c|c|c|c|c|c|c|c|c|c|c|}
\hline Type of coin & $\mathrm{Au} \%$ & $\sigma$ & $\mathrm{Ag} \%$ & $\sigma$ & $\mathrm{Cu} \%$ & $\sigma$ & Pd ppm & $\sigma$ & Sn ppm & $\sigma$ & Sb ppm & $\sigma$ & Fe ppm & $\sigma$ \\
\hline \multicolumn{15}{|l|}{ Obsidional } \\
\hline XII florins 1645 & 86,1 & 0,7 & 12,57 & 0,25 & 0,48 & 0,06 & 167 & 38 & 201 & 50 & 151 & 19 & 985 & 43 \\
\hline VI florins 1645 & 87,2 & 0,5 & 11,20 & 0,51 & 0,76 & 0,03 & 111 & 27 & 258 & 62 & 159 & 31 & 1129 & 58 \\
\hline III florins 1645 & 87,0 & 0,6 & 11,45 & 0,11 & 0,53 & 0,02 & 210 & 47 & 229 & 59 & 186 & 30 & 935 & 60 \\
\hline III florins 1646 & 87,9 & 0,8 & 10,59 & 0,23 & 0,86 & 0,05 & 120 & 33 & 271 & 42 & 201 & 27 & 1250 & 101 \\
\hline \multicolumn{15}{|l|}{ Rio de Janeiro } \\
\hline 4000 réis 1699 & 92,6 & 0,6 & 4,52 & 0,04 & 2,60 & 0,13 & 72 & 11 & 142 & 31 & 108 & 16 & 309 & 26 \\
\hline 4000 réis 1700 & 93,2 & 0,7 & 3,73 & 0,39 & 2,82 & 0,14 & 75 & 19 & 82 & 25 & 122 & 10 & 195 & 23 \\
\hline 2000 réis 1699 & 91,9 & 0,6 & 5,61 & 0,13 & 2,34 & 0,10 & 99 & 28 & 129 & 27 & 149 & 35 & 307 & 77 \\
\hline 2000 réis 1700 & 92,2 & 0,5 & 4,84 & 0,07 & 2,49 & 0,11 & 91 & 21 & 121 & 24 & 107 & 12 & 199 & 15 \\
\hline 1000 réis 1699 & 91,7 & 0,5 & 5,36 & 0,04 & 2,35 & 0,12 & 87 & 16 & 178 & 39 & 98 & 19 & 215 & 16 \\
\hline 1000 réis 1700 & 92,3 & 0,8 & 4,87 & 0,43 & 2,51 & 0,11 & 101 & 27 & 197 & 27 & 190 & 37 & 357 & 55 \\
\hline
\end{tabular}

Table 1: Compositions of the gold coins analysed by SR-XRF (Bahia coins were published in Guerra, 2004).

Tableau 1: Résultats des analyses élémentaires par SR-XRF des monnaies en or étudiées (pour les monnaies émises in Bahia cf. Guerra, 2004).
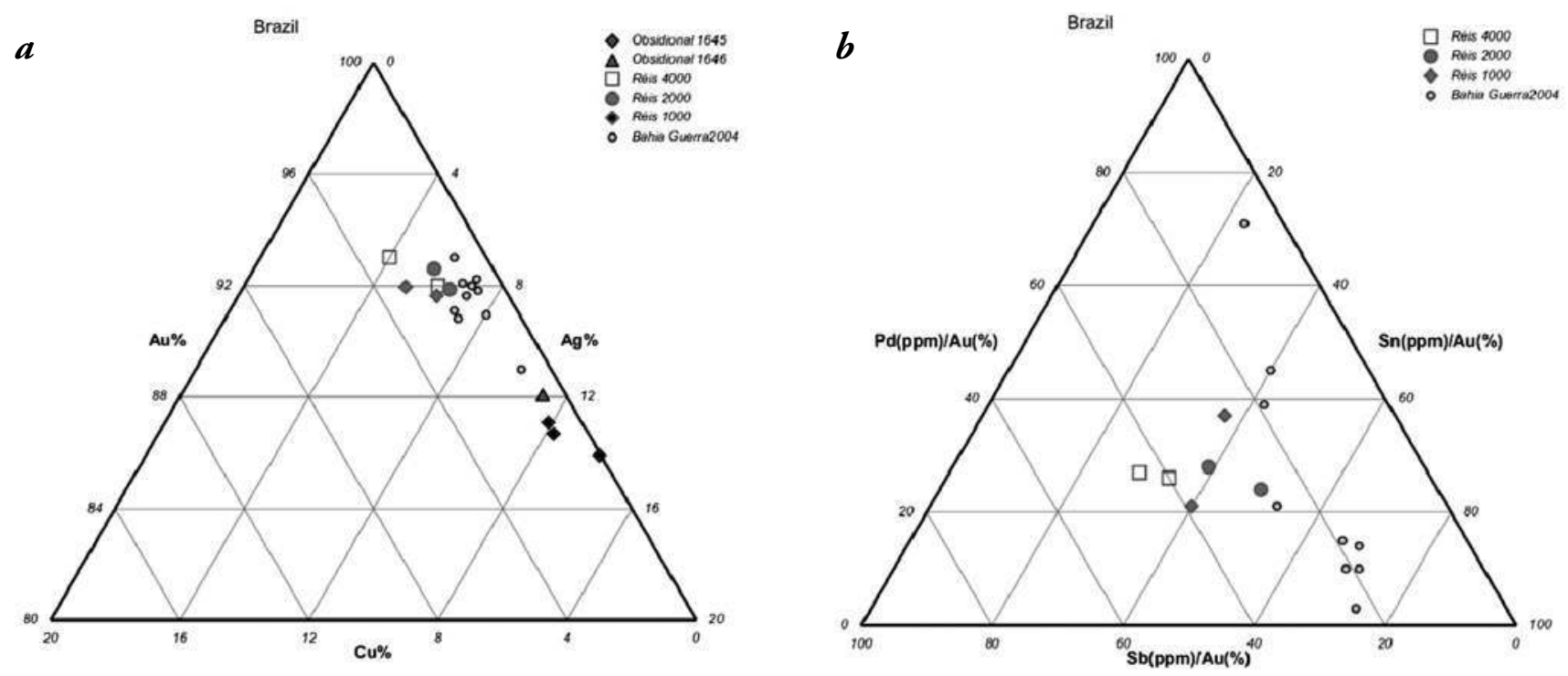

Figure 2: Ternary diagram for the analysed coin representing the concentrations of (a) the major elements $\mathrm{Au}-\mathrm{Ag}-\mathrm{Cu}(\mathrm{in} \%)$ and (b) the trace elements $\mathrm{Sn}-\mathrm{Sb}-\mathrm{Pd}$ (in ppm) normalised to $\mathrm{Au}$ (in \%) and to $100 \%$.

Figure 2 : Diagramme ternaire présentant les teneurs en (a) éléments majeurs Au-Ag-Cu (in \%) et (b) éléments traces $S n-S b$-Pd (en ppm) normalisées à la teneur en Au (en \%) et à 100\%.

Guerra, 2002) and from the Portuguese coins struck during their control of São Jorge da Mina on the African Coast (Guerra, 2005). These results seem to indicate that African gold was not used to fabricate the obsidional coins. The second assumption - melting of gold tableware - can only be verified by analyses of Brazilian and Dutch gold tableware from the period under consideration.

\section{DisCUSSION AND CONCLUSION}

The analysis of the first coins struck in Brazil, issued by the United West India Company in Pernambuco, showed the use of a base alloy of poorer quality than the monetary alloy used in the first itinerant Brazilian mint. Both the 
Bahia (1694-1698) and Rio de Janeiro (1699-1700) mints issued coins made of an equivalent alloy of good quality. The measurement of trace elements characteristic of the gold's provenance, and the comparison with results previously obtained for Brazilian, Portuguese, Latin American and North African gold coins, showed the similarity of the gold used in the first Rio de Janeiro and Bahia mints. However, only the quantification of the Pt contents would allow drawing a conclusion concerning the use of the same mixture of South American gold. The high contents of Sn, $\mathrm{Sb}$ and $\mathrm{Pd}$ measured for the obsidional coins do not confirm the assumption that gold carried by the Dutch ships circulating from the African Coast to Brazil and to Netherlands was melted to fabricate this coinage. Further analyses appear, however, necessary in order to confirm these results and to show whether gold Brazilian or Dutch tableware could have been used for this purpose.

\section{Acknowledgements}

The authors wish to thank Dr. Martin Radtke for his assistance and helpful comments regarding data calculation and are grateful to the CNRS (France) and to the CNPq (Brazil) for financial support.

\section{References}

Gondonneau, A. and Guerra, M.F., 2002. The circulation of precious metals in the Arabic Empire: the case of the Near and the Middle East. Archaeometry 44(4): 473 \& 599.

Guerra, M.F., 2004. The circulation of South American precious metals in Brazil at the end of the $17^{\text {th }}$ century. Journal of Archaeological Science 31(9): 1225-1236.

Guerra, M.F., 2005. The circulation of gold in the Portuguese area from the $5^{\text {th }}$ to the $18^{\text {th }}$ century, in A. Perea, I. Montero, O. Garcia-Vuelta (eds.), Ancient gold technology: America and Europe. Madrid: Anejos de AespA XXXII, CSIC, 423-431.

Lima F.C.G.C., 2005. Uma Análise Crítica da Literatura Sobre a Oferta e a Circulação de Moeda Metálica no Brasil nos Séculos XVI e XVII. Estudos Econômicos 35(1): 169-201.

Noya Pinto, V., 1979. O ouro brasileiro e o comércio anglo-português. Brasiliana 371. São Paulo, Nacional Edição.

Van Espen, P., Nullens, H. and Adams, F., 1977. A computer analysis of X-ray fluorescence spectra. Nuclear Instruments and Methods 142 (1-2): 243-250.

Vieira, R.M.L., Guerra, M.F., Scorzelli, R.B., Souza Azevedo, I., Duttine, M. and Brito Pereira, C.E., 2007. Estudo preliminar de algumas moedas holandesas da colecçáo Museu Histórico Nacional do Rio de Janeiro. Revista Brasileira de Arqueometria, Restauração e Conservação 1(6): 296-300. 